\title{
Preparation and Characterization of Copper Borates as
}

\section{Lubricant Additives}

\author{
Burcu Alp, Sevdiye Atakul Savrik and Devrim Balkose \\ Department of Chemical Engineering, İzmir Institute of Technology, Gülbahçe Urla Izmir 35430, Turkey
}

Received: April 05, 2014 / Accepted: April 17, 2014 / Published: April 25, 2014.

\begin{abstract}
The present study attempts the preparation of copper borate as a lubricating oil additive by the reaction of copper nitrate and borax solutions. Effects of borax/ copper ratio, surface active agent (Span 60), pH, temperature and mixing time on properties of the products were investigated. The obtained products were not pure form; therefore they were analyzed in detail. They were characterized by color measurement, X-ray diffraction, SEM, zeta sizer, ICP, EDX, TG, DSC, CHNS analysis and FTIR spectroscopy. Mainly $\mathrm{Cu}_{2}(\mathrm{OH})_{3} \mathrm{NO}_{3}$ with nitrate ions partially substituted with borate ions was obtained at $\mathrm{pH}$ 3.7. There were borate ions equivalent to 0.32 mols of $\mathrm{Cu}(\mathrm{BO})_{2}$ per mol of $\mathrm{Cu}_{2}(\mathrm{OH})_{3} \mathrm{NO}_{3}$. The borate ions should have replaced partially the nitrate ions in $\mathrm{Cu}_{2}(\mathrm{OH})_{3} \mathrm{NO}_{3}$ without changing its crystal structure. On the other hand, $\mathrm{Cu}\left(\mathrm{BO}_{2}\right)_{1.5}(\mathrm{OH})_{0.74} \cdot\left(\mathrm{H}_{2} \mathrm{O}\right)_{0.15}$ was produced at $\mathrm{pH} 10.2$. It also contained $0.11 \mathrm{~mol}$ $\mathrm{NO}_{3}{ }^{-}$per mol. By mixing of dilute solutions at $\mathrm{pH} 8.2$ and drying at room temperature nanoparticles of $\mathrm{Cu}\left(\mathrm{BO}_{2}\right)_{1.5}\left(\mathrm{H}_{2} \mathrm{O}\right)_{6}$ having 0.05 $\mathrm{NO}_{3}{ }^{-}$per mol was obtained. The precipitates obtained at $\mathrm{pH} 10.1$ and 8.2 were tested as lubricant additives. When they were added to lubricating oil with Span 60 , the friction coefficient was reduced $28 \%$ and $65 \%$ for the precipitates prepared at $\mathrm{pH} 10.1$ and 8.2 , respectively.
\end{abstract}

Key words: Copper borate, copper hydroxyl nitrate, lubricant additive, characterization.

\section{Introduction}

The materials showing antiwear and extreme pressure functions and used for the modification of the surfaces in the lubricating oils can be borate based material [1]. Copper borate has been the focus of much attention, as it possesses a good combination of properties, such as environmentally friendly lubrication, wood preservation, and fire retardancy. Hydrophobic copper borate particles captured attention as a solid lubricant since it reduced the friction coefficient of the base oil [2]. 1\% hydrophobic copper borate particles in mineral oil reduced the friction coefficient of the base oil from 0.116 to 0.012 . Moreover copper nanoparticles dispersed in base oil also improved lubrication behavior. The wear scar

Corresponding author: Devrim Balkose, Dr., professor, research fields: polymer composites, additives to polymers and lubricants and water material interactions. E-mail: devrimbalkose@gmail.com. diameter and the friction coefficient were reduced $16 \%$ and $8 \%$ respectively at $80{ }^{\circ} \mathrm{C}$. Local high temperature and high pressure due to direct contact of two surfaces initiate melting of $\mathrm{Cu}$ nanoparticles and forming a copper protective film with low nano-hardness and elastic modulus of worn surface [3].

$\mathrm{Hu}$ et al. [1], Zheng et al. [2] and Shvartz and Boleuseva $[4,5]$ described the preparation of copper borate from borax decahydrate and water soluble copper salts. Formation of $\mathrm{Cu}_{3} \mathrm{~B}_{2} \mathrm{O}_{6}[1], \mathrm{CuBO}_{2}$ [2] and $2 \mathrm{CuO} \cdot 3 \mathrm{~B}_{2} \mathrm{O}_{3} \cdot \mathrm{nH}_{2} \mathrm{O} \cdot \mathrm{mNa}_{2} \mathrm{SO}_{4}$ [4] were reported by mixing aqueous solutions of copper salts and borax decahydrate. The conditions under which tricuprotetraborate hexahydrate $3 \mathrm{CuO} .2 \mathrm{~B}_{2} \mathrm{O}_{3} \cdot 6 \mathrm{H}_{2} \mathrm{O}$ was formed were as follows: $\mathrm{CuSO}_{4}: \mathrm{H}_{3} \mathrm{BO}_{3}: \mathrm{NaOH}$ 1:4:(3.25-3.5), $\mathrm{pH} 7.5-8.0,80{ }^{\circ} \mathrm{C}$ [5]. The synthesis duration was $4 \mathrm{~h}$. Under other conditions, amorphous finely dispersed tricuprotetraborate with a significant amount of impurities $\left(\mathrm{Na}_{2} \mathrm{SO}_{4}, \mathrm{Cu}(\mathrm{OH})_{2}\right.$, etc.) was 
formed [5].

$\mathrm{Cu}_{3} \mathrm{~B}_{6} \mathrm{O}_{12} \cdot \mathrm{H}_{2} \mathrm{O}$ was synthesized by heating cupric oxide and boric acid at $700{ }^{\circ} \mathrm{C}$ and at $7.5 \mathrm{GPa}$ [6]. The crystals were built up from corner sharing of $\mathrm{BO}_{4}$ tetrahedra forming a three dimensional network with channels along c-axis. Inside these channels, the water molecules and a part of the copper ions took place.

There are parallel reactions that could occur in the mixtures of aqueous copper nitrate and sodium borate solutions. The basic borate solutions may lead to the formation of copper hydroxy nitrate besides copper borate. Conventionally, copper hydroxy nitrate is synthesized by mixing aqueous solutions of copper nitrate and sodium carbonate [7]. Depending on the ratio of the reactants different copper hydroxy nitrates can be formed. They are $\mathrm{Cu}_{2} \mathrm{NO}_{3}(\mathrm{OH})_{3}, \mathrm{CuNO}_{3} \mathrm{OH}$, $\mathrm{Cu}_{3}\left(\mathrm{NO}_{3}\right)(\mathrm{OH})_{5} \cdot 2 \mathrm{H}_{2} \mathrm{O}$ and $\mathrm{Cu}_{3}\left(\mathrm{NO}_{3}\right)_{2}(\mathrm{OH})_{4}$ [7]. $\mathrm{Cu}_{2}$ $(\mathrm{OH})_{3} \mathrm{NO}_{3}$ was also obtained by mixing aqueous $\mathrm{Mg}(\mathrm{OH})_{2}$ dispersions with copper nitrate solutions [8]. Another method was the addition of ammonia solution to copper nitrate solution [9]. Heating hydrated copper nitrate above $140{ }^{\circ} \mathrm{C}$ was an alternative method to synthesize copper hydroxy nitrate [10]. Mixing dilute copper nitrate and sodium hydroxide solutions in a jet is a convenient method to produce nanoplatelets [11].

$\mathrm{Cu}_{2}(\mathrm{OH})_{3} \mathrm{NO}_{3}$ was used as a raw material for other products. The $\mathrm{Cu}(\mathrm{OH})_{2}$ nanorods were prepared from direct reaction of $\mathrm{Cu}_{2}(\mathrm{OH})_{3} \mathrm{NO}_{3}$ with aqueous $\mathrm{NaOH}$ solution at room temperature [12]. Other salts were prepared from $\mathrm{Cu}_{2}(\mathrm{OH})_{3} \mathrm{NO}_{3}$ by anion exchange of nitrate ions [10, 13]. Partial substitution of nitrate ions by benzoate ions was possible by mixing copper hydroxynitrate with aqueous sodium benzoate solution at $25{ }^{\circ} \mathrm{C}$ for $24 \mathrm{~h}$ and coordination of carboxylic acid groups were bidendate in structure [10]. Perclorate ions were substituted with nitrate ions of copper hydroxy nitrate mixed with aqueous sodium perchlorate solution in eight days [14]. Copper hydroxydodecyl sulfate was obtained by substituting the nitrate ions in $\mathrm{Cu}_{2}(\mathrm{OH})_{3} \mathrm{NO}_{3}$ with the dodecyl sulfate ions. The distance between the layers was expanded due to introduction of dodecyl sulfate between the layers [9].

The present study aims at preparation of nanosized copper borate particles by mixing copper nitrate and borax solutions. The effects of concentration of reactants, surface active agent (Span 60) additive, $\mathrm{pH}$, temperature and mixing time on chemical composition and morphology of the products were investigated. The products were characterized by color measurement, SEM, zetasizer, X-ray diffraction, FTIR spectroscopy, thermal gravimetric analysis, differential scanning calorimetry, inductively coupled plasma, EDX and CHNS analysis. The products were used as an additive to a lubricating oil to improve its tribological properties.

\section{Experiments}

\subsection{Precipitation Reaction}

Copper (II) nitrate, $\mathrm{Cu}\left(\mathrm{NO}_{3}\right)_{2} \cdot 2.5 \mathrm{H}_{2} \mathrm{O}$ (from Aldrich), borax decahydrate, $\mathrm{Na}_{2} \mathrm{~B}_{4} \mathrm{O}_{7} \cdot 10 \mathrm{H}_{2} \mathrm{O}$ (from Etibor with purity $99 \%$ ) and $\mathrm{NaOH}$ (from Merck) were used in preparation of copper borates. Sorbitan monostearate (Span 60, from Aldrich) $\left(0.02 \mathrm{~mol} \cdot \mathrm{dm}^{-3}\right)$ was used as a surface active agent. $0.1-2.5 \mathrm{~mol} \cdot \mathrm{dm}^{-3}$ Copper (II) nitrate and $0.1-1 \mathrm{~mol} \cdot \mathrm{dm}^{-3}$ borax decahydrate solutions having different concentrations were mixed in proportions shown in Table 1 to prepare copper borates. Mainly there different methods were used in preparation of the precipitates. The concentrations and proportions of the Method 1 and Method 2 were inspired from Zheng et al. [2] and Shvartz and Belousova [4, 5] previous studies, respectively. Copper nitrate was used in the present study instead of copper sulfate used in previous studies. As surface active agent Span 60 was used instead of the phosphate ester used by Zheng et al. [2]. Dilute $\mathrm{Cu}\left(\mathrm{NO}_{3}\right)_{2}$ and borax solutions were mixed $25{ }^{\circ} \mathrm{C}$ to prevent particle growth and agglomeration and to obtain nano sized copper borate particles in Method 3. Copper (II) solutions were added drop by drop to borax solutions which were stirred at $450 \mathrm{rpm}$ using a magnetic stirrer. 
Table 1 Experimental composition, pH, temperature and mixing period.

\begin{tabular}{lllllllll}
\hline Method & $\begin{array}{l}\text { Borax solution Copper Solution Borax/Copper } \\
\left(\mathrm{mol} \cdot \mathrm{dm}^{-3}\right)\end{array}$ & $\begin{array}{l}\mathrm{NaOH} / \mathrm{Copper} \\
(\mathrm{mol} / \mathrm{mol})\end{array}$ & $\begin{array}{l}\text { Final Span 60 } \\
\text { concentration } \\
\left(10^{5} \mathrm{~mol}^{-3} \mathrm{dm}^{-3}\right)\end{array}$ & $\mathrm{pH}$ & $\begin{array}{l}\text { Temperature } \\
\left({ }^{\circ} \mathrm{C}\right)\end{array}$ & $\begin{array}{l}\text { Time } \\
(\mathrm{h})\end{array}$ \\
\hline 1 & 0.1 & 2 & 0.25 & 0 & 0 & 3.7 & $40-70$ & $2-4$ \\
1 & 0.1 & 2 & 0.25 & 0 & 3.3 & 3.7 & $40-70$ & $2-4$ \\
2 & 0.3 & 2.5 & 0.85 & 2.88 & 0 & 10.1 & 60 & 3 \\
3 & 0.1 & 0.1 & 1.0 & 0 & 0 & 8.2 & 25 & 2 \\
3 & 0.1 & 0.1 & 1.0 & 0 & 2 & 8.2 & 25 & 2 \\
\hline
\end{tabular}

Since the copper nitrate solutions are acidic and borax solutions are basic their mixtures had a $\mathrm{pH}$ value depending on their proportions. For example when $0.1 \mathrm{~mol} \cdot \mathrm{dm}^{-3} \mathrm{Cu}\left(\mathrm{NO}_{3}\right)_{2}$ solution and $0.1 \mathrm{~mol} \cdot \mathrm{dm}^{-3}$ borax solution were mixed in equimolar quantities the final $\mathrm{pH}$ value was 8.2. Thus mixtures with different final $\mathrm{pH}$ values were obtained by changing the mol ratio of borax to copper or by adding $1 \mathrm{~mol} \cdot \mathrm{dm}^{-3} \mathrm{NaOH}$ solution. The final $\mathrm{pH}$ of the mixtures were measured and the obtained precipitates were filtered, washed with water twice and then dried for $2 \mathrm{~h}$ at $60{ }^{\circ} \mathrm{C}$ in the air circulating oven.

\subsection{Characterization of the Precipitates}

The colors of the precipitates were measured by using Avantes AvaMouse Fiberoptic spectrophotometer. The morphologies of the samples were examined using QUANTA 250F Scanning Electron Microscope (SEM). The particle size of the powders were measured by Malvern 2000 zetasizer. X-ray diffraction diagrams were obtained by Phillips x'pert pro x-ray diffractometer employing Ni-filtered $\mathrm{Cu} \mathrm{K} \mathrm{K}_{\alpha}$ radiation. FTIR spectra of the samples were taken with SHIMADZU FTIR-8400S using $\mathrm{KBr}$ disc technique. TG analysis was performed by using SHIMADZU TGA-51 to determine changes in weight with heating under nitrogen flow at $40 \mathrm{~cm}^{3} \cdot \mathrm{min}^{-1}$ rate and at a heating rate of $10{ }^{\circ} \mathrm{C} \cdot \mathrm{min}^{-1}$ up to $600{ }^{\circ} \mathrm{C}$. DSC analysis was carried out using SHIMADZU DSC-50 by heating the samples under $40 \mathrm{~cm}^{3} \mathrm{~min}$ nitrogen flow and at a heating rate of $10{ }^{\circ} \mathrm{C} \cdot \mathrm{min}^{-1}$ up to $600{ }^{\circ} \mathrm{C}$. Thermal decomposition behavior of the product was studied by in situ temperature-programmed diffuse reflectance Fourier transform infrared spectroscopy (DRIFTS) method using a FTS 3000MX Digilab Excalibur Series spectrophotometer. The samples were heated in situ from the room temperature up to $500{ }^{\circ} \mathrm{C}$ at a heating rate of $2{ }^{\circ} \mathrm{C} / \mathrm{min}$ under vacuum $(0.1 \mathrm{~Pa})$ in a praying mantis diffuse reflection attachment (Harrick Scientific Products Inc.) equipped with a high-temperature, low-pressure reaction chamber (HVC-DRP, Harrick Scientific Products Inc.). The reaction chamber has two $\mathrm{CaF}_{2}$ windows and one glass window for observation. The pressure in the chamber was controlled with Leybold PT50 Vacuum system.

The copper content of the samples were determined using an inductively coupled plasma atomic emission spectrometer with axial plasma (ICP-AES) (Liberty Series II, Varian) after dissolving them in nitric acid. Boron content was determined by adding mannitol after masking copper ions with ethylene diamine tetra acetic acid (EDTA) at $\mathrm{pH} 9$ and titrating released protons with $\mathrm{NaOH}$. EDX analysis was carried out using QUANTA 250F SEM. Besides, elemental analysis of the samples was performed using CHNS Analyzer (LECO Corporation St. Joseph MI USA).

\subsection{Lubricant Preparation and Characterization}

The precipitates obtained by method $2(\mathrm{pH} 10.1)$ and method 3(without Span 60, pH 8.2) described in Table 1 were employed as lubricant additives to oil. In a typical experiment, $50 \mathrm{~cm}^{3}$ of spindle oil (PETROFER A.Ş., Turkey), $0.5 \mathrm{~g}$ of sorbitan monostearate and $0.5 \mathrm{~g}$ of the precipitate were mixed thoroughly at $600 \mathrm{rpm}$ rate and at $160{ }^{\circ} \mathrm{C}$ for one hour on a magnetic hot plate and left to cool down to room temperature by 
continuous stirring. A four ball tester (Ducom) was used to determine the friction coefficient and wear scar diameter. The tests were performed according to ASTM D 4172-94 at $392 \mathrm{~N}$ and the test duration was 1 $\mathrm{h}$ at $75{ }^{\circ} \mathrm{C}$. Test balls were made from AISI standard steel No. E-52100 and had $12.7 \mathrm{~mm}$ diameter.

Microphotographs of the wear scars of the three fixed and one rotating test balls were taken by using Olympus BX 60 equipped with Canon Power shot 590IS camera.

\section{Results and Discussion}

\subsection{Colors of the Precipitates}

The color of a substance can be defined by L, a and b coordinates. While the $\mathrm{L}$ value describe the lightness of the color, the values of $\mathrm{a}$ and $\mathrm{b}$ indicate the color falls along red-green axis, and yellow-blue axis, respectively. The positive and negative values of a represent redness and greenness of the color respectively. Positive values of " $b$ " represents yellowness and negative values of " $b$ " represents blueness of the color. Representative colors of the precipitates are seen in Fig. 1 and the $L$, a, and b values are listed in Table 2, as well. The precipitates obtained at pH 3.7 and 8.2 had the same blue color and $\mathrm{L}, \mathrm{a}$ and $\mathrm{b}$ values as 73, -20 and -26.7 , respectively. On the other hand $\mathrm{L}, \mathrm{a}$ and $\mathrm{b}$ values of the precipitate obtained at $\mathrm{pH}$ 10.1 were $66,-17.9$ and -3.3 . The sample obtained at $\mathrm{pH} 10.1$ was darker and less blue since it had a lower L value and a less negative $b$ value than the color of the precipitates obtained by at $\mathrm{pH} 3.7$ and 8.2.

\subsection{Morphologies of the Precipitates}

The particles formed in precipitation reaction at $\mathrm{pH}$ 3.7 are in planar geometry with average dimensions of $2 \pm 0.2 \mu \mathrm{m}$ length and $1 \pm 0.1 \mu \mathrm{m}$ width and $100 \pm 10$ $\mathrm{nm}$ thickness as seen in the representative SEM images of the samples prepared under different conditions (Figs. 2a and 2b). They were heavily intertwined with each other. The particles were larger in size but had the same morphology with the copper hydroxyl nitrate nanoplatelets prepared by previous investigators [11]. The morphologies of the precipitates formed at $\mathrm{pH} 3.7$ but at different temperatures, mixing time periods and

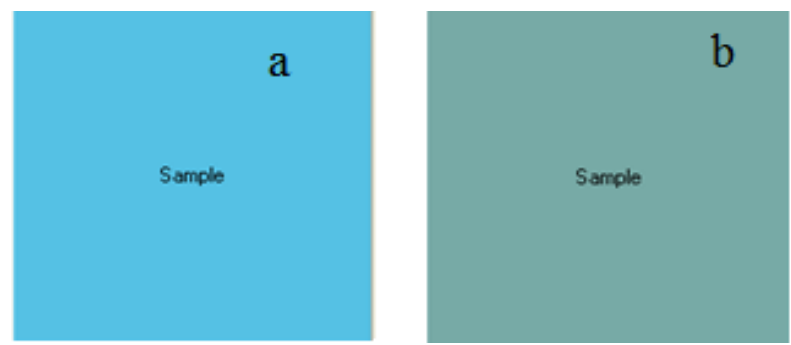

Fig. 1 The representative colors of the precipitates prepared at (a) pH 3.7 and (b) 8.2 10.1.

Table $2 \mathrm{~L}$, a, b values of products.

\begin{tabular}{lllll}
\hline Method & $\mathrm{pH}$ & $\mathrm{L}$ & $\mathrm{a}$ & $\mathrm{b}$ \\
\hline 1 & 3.7 & 73 & -20 & -26.7 \\
2 & 10.1 & 66 & -17.9 & -3.3 \\
3 & 8.2 & 73 & -20 & -26.7 \\
\hline
\end{tabular}
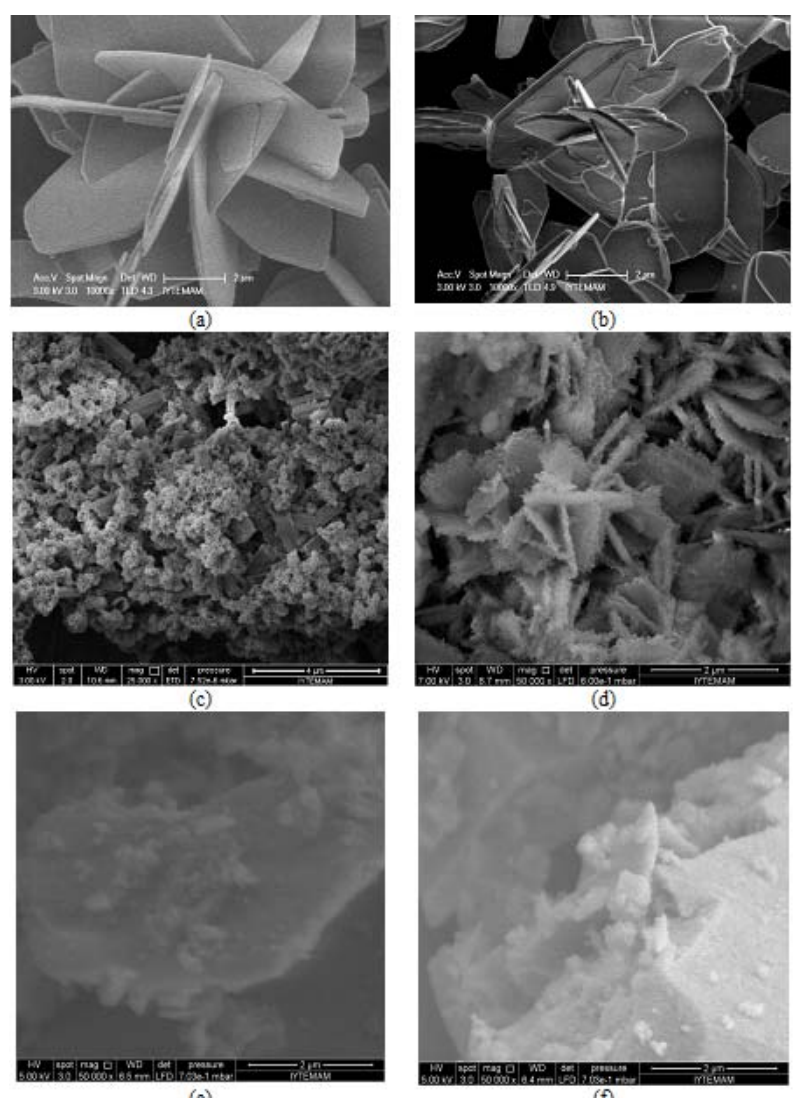

(e)

(f)

Fig. 2 SEM images of samples produced at (a) $70{ }^{\circ} \mathrm{C}$ and without Span 60 for $4 \mathrm{~h}$ at $\mathrm{pH} 3.7$ (b) $70{ }^{\circ} \mathrm{C}$ and with Span 60 for $4 \mathrm{~h}$ at $\mathrm{pH} 3.7$ (c) $60^{\circ} \mathrm{C}$, without Span 60 at $\mathrm{pH} 10.1$ (scale $4 \mu \mathrm{m})(\mathrm{d}) 60^{\circ} \mathrm{C}$, without span 60 at pH 10.1 (scale $2 \mu \mathrm{m}$ ) (e) $25^{\circ} \mathrm{C}$ and without Span 60 at pH 8.2 (scale $2 \mu \mathrm{m}$ ) (c) $25^{\circ} \mathrm{C}$ and with Span 60 at pH 8.2 (scale $2 \mu \mathrm{m}$ ). 
in the presence and the absence of Span 60 at pH 3.7 were also very similar to each other as seen in Fig. S1. The morphologies of the particles did not change with temperature, time of mixing and presence of Span 60 during preparation.

There are two different types of particles in the precipitate formed in at $\mathrm{pH} 10.1$ as seen in Figs. 2c and $2 \mathrm{~d}$. Prismatic particles with $2 \mu \mathrm{m} \times 0.25 \mu \mathrm{m} \times 0.25 \mu \mathrm{m}$ and platelets with $1.7 \mu \mathrm{m} \times 1.7 \mu \mathrm{m} \times 0.13 \mu \mathrm{m}$ sizes were formed respectively. The surfaces of the platelets in Fig. 2c are covered with much smaller particles. The particles prepared without and with Span 60 at $\mathrm{pH} 8.2$ were nanosized and they were agglomerated to larger sizes as seen in Figs. 2e and $2 \mathrm{f}$, respectively.

\subsection{Particle Size Distribution}

The particles prepared at $\mathrm{pH} 3.1$ were flat in shape and their sizes were $2 \pm 0.2 \mu \mathrm{m}$ length and $1 \pm 0.1 \mu \mathrm{m}$ width and $100 \pm 10 \mathrm{~nm}$. Since they were in an agglomerated state their size was not measured by zetasizer. The particle size distribution of the powder obtained at pH 10.1 determined by zeta sizer (Fig. 3a) was bidisperse. The average size of $35.3 \%$ of the particles was $183 \mathrm{~nm}$ and $64.7 \%$ of the particles had $715 \mathrm{~nm}$ size. The width of the distribution curves was 62 and $244 \mathrm{~nm}$, respectively. Since the particles had platelet shape and zetasizer assumes that they were spherical, the bidisperse distribution observed was due to flat particle shape. The lower particle size $(183 \mathrm{~nm})$ and the higher size $(715 \mathrm{~nm})$ should have corresponded to the thickness and length of the particles as seen in

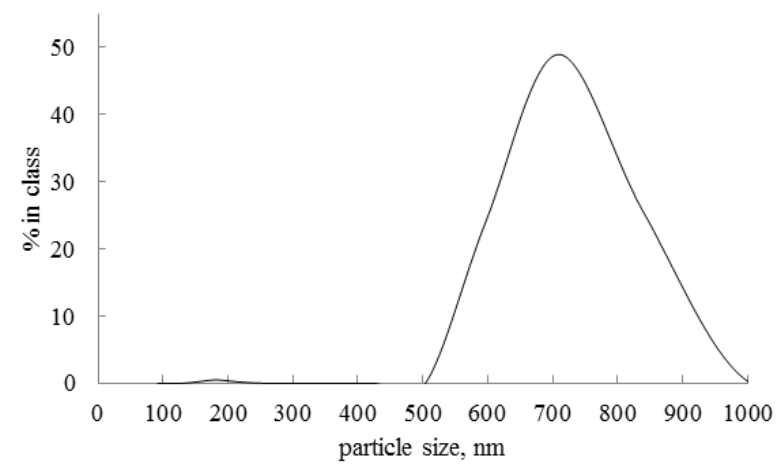

(a)
Fig. 3a.

The particle size distribution of the particles obtained at $\mathrm{pH} 8.2$ was very narrow as seen in Fig. 3 b. The particles of the powder prepared at $\mathrm{pH} 8.2$ had 27 and $44 \mathrm{~nm}$ sizes for the cases without and with Span 60 respectively. The breadth of the distribution curve was $14 \mathrm{~nm}$ for both cases. The nano particles formed at $\mathrm{pH}$ 8.2 were in larger size when Span 60 was added as indicated by curve 1 and curve 2 in Fig. $3 b$.

\subsection{Crystal Structure of the Precipitates}

X-ray diffraction diagram of the precipitate prepared at $70{ }^{\circ} \mathrm{C}$ with Span 60 and reacted for $4 \mathrm{~h}$ at $\mathrm{pH} 3.7$ is seen in Fig. 4a. XRD patterns of all the samples prepared at $\mathrm{pH} 3.7$ were identical to this pattern. The peak positions and the relative intensities of the peaks indicated that the samples had the same $x$-ray diffraction diagram of $\mathrm{Cu}_{2}(\mathrm{OH})_{3} \mathrm{NO}_{3}$ according to the studies of Park and Kim [12] and Aguirre et $\mathrm{al}^{8}$. The samples had main reflections at 2 theta values of $12.7,25.6,33.48,36.4,39.6$ for reflections of 001,002 , 120, 121, 202 planes as indicated in JCPDS card number 15-0014 for monoclinic crystals of $\mathrm{Cu}_{2}(\mathrm{OH})_{3} \mathrm{NO}_{3}$. There were no diffraction peaks related to $\mathrm{Cu}\left(\mathrm{BO}_{2}\right)_{2}$ and $\mathrm{CuBO}_{2}$ shown in JCPDS cards 01-1472 and 28-1286, respectively in the X-ray diagrams of the precipitates obtained in the present study. The size of the crystals (B) perpendicular to 001 and 120 planes were in the range of 76 to $104 \mathrm{~nm}$ as determined from the breadth of the related diffraction peaks and by Scherrer Equation (Eq. (1)) and they were

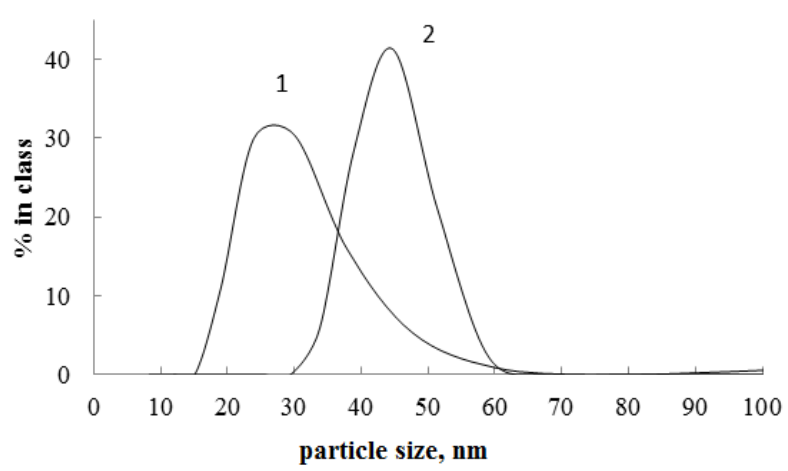

(b)

Fig. 3 Particle size distribution of powders obtained at (a) $\mathrm{pH} 10.1$ (b) $\mathrm{pH} 8.2$ without Span 60 (curve 1) and with Span 60 (curve 2). 


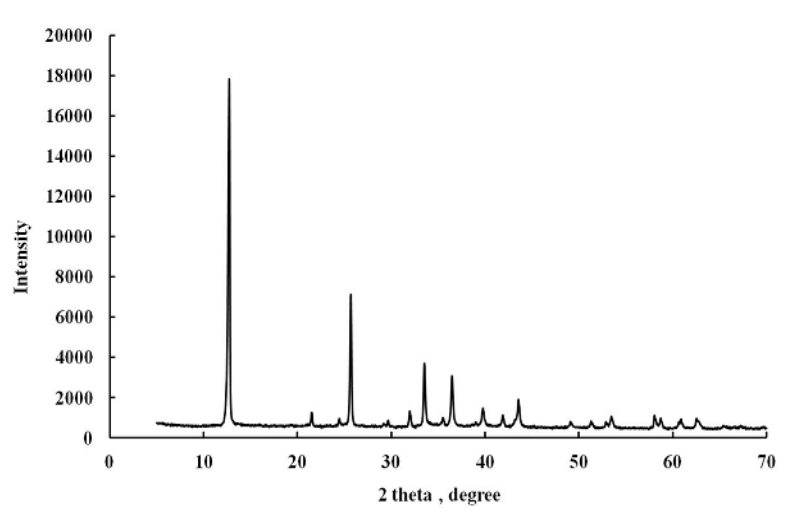

(a)

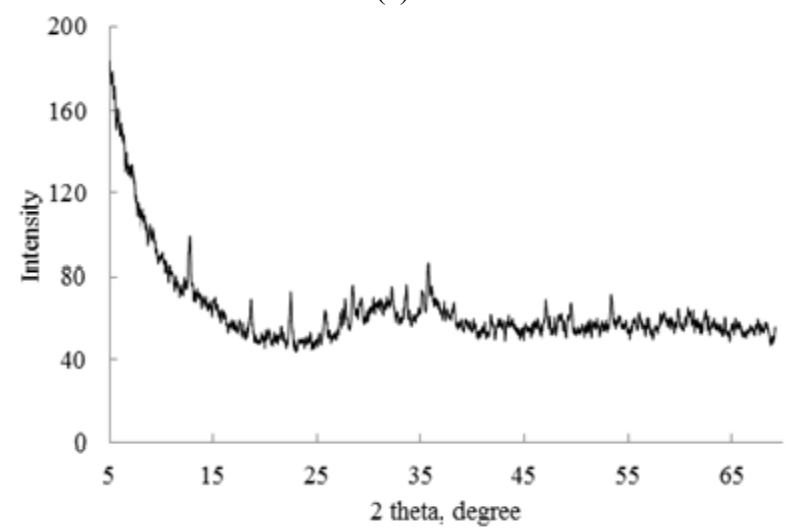

(b)

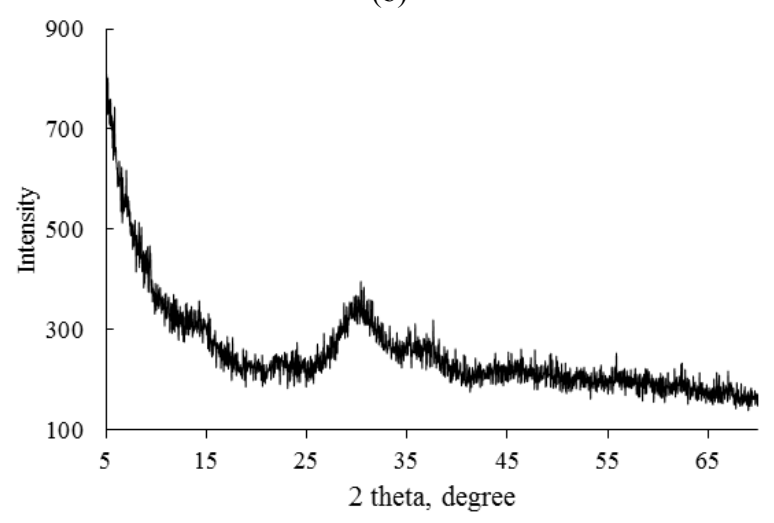

(c)

Fig. $4 \mathrm{X}$-ray diffraction of sample prepared (a). at $70{ }^{\circ} \mathrm{C}$ with Span 60 and reacted for $4 \mathrm{~h}$ at $\mathrm{pH} 3.7$, (b) at $\mathrm{pH} 10.1$ without Span 60, (c) at pH 8.2 without Span 60.

were reported in Table 3.

$$
B=\mathrm{K} \lambda / L \cos \theta
$$

where, $\mathrm{K}$ is constant taken as $0.9, \lambda$ is the wavelength of the X-rays, $0.146 \mathrm{~nm}$ for the present case, $\mathrm{L}$ is the breadth of the diffraction peak in radians at $\theta$ degree. However, the crystals were self-assembled to planar
Table 3 Size of crystals $(\mathrm{nm})$ from 001 planes and 120 planes at at $2 \theta$ values of $12.7^{\circ}$ and $33.48^{\circ}$, respectively for $\mathrm{Cu}_{2}(\mathrm{OH})_{3} \mathrm{NO}_{3}$ crystals present in the precipitate obtained prepared at $\mathrm{pH} 3.7$ predicted by Scherrer equation.

\begin{tabular}{llllll}
\hline \multirow{2}{*}{ Time (h) Span 60 (\%) } & \multicolumn{3}{c}{001 planes } & \multicolumn{2}{c}{120 planes } \\
\cline { 3 - 6 } & & $40{ }^{\circ} \mathrm{C}$ & $70{ }^{\circ} \mathrm{C}$ & $40{ }^{\circ} \mathrm{C}$ & $70{ }^{\circ} \mathrm{C}$ \\
\hline 2 & None & 94 & 100 & 83 & 93 \\
4 & None & 76 & 100 & 83 & 83 \\
2 & Present & 80 & 80 & 98 & 83 \\
4 & Present & 80 & 100 & 104 & 83 \\
\hline
\end{tabular}

structures having $2 \pm 0.2 \mu \mathrm{m}$ length and $1 \pm 0.1 \mu \mathrm{m}$ width on the average as seen in Fig. 2.

The X-ray diffraction diagram of powders obtained at $\mathrm{pH} 10.1$ is seen in Fig. 4b. There are crystalline peaks overlapped with the broad amorphous scattering. There were diffraction peaks at $2 \theta$ values of $12.8^{\circ}$, $18.7^{\circ}, 22.4^{\circ}, 24.4^{\circ}, 28.5^{\circ}, 33.5^{\circ}, 35.6^{\circ}, 46.2^{\circ}, 48.5^{\circ}$, $65.3^{\circ}$. These peaks were nearly identical with the peaks at $2 \theta$ values of $12.5^{\circ}, 20.6^{\circ}, 22.9^{\circ}, 24.2^{\circ}, 27.2^{\circ}, 33.9^{\circ}$, $35.4^{\circ}, 46.9^{\circ}, 48.8^{\circ}, 63.8^{\circ}$ of $\mathrm{CuBO}_{2}$ reported in JSPDS card number 28-1256. A phase isomorphous with $\mathrm{CuBO}_{2}$ was present in the powder. $\mathrm{Cu}_{2}\left[\left(\mathrm{BO}(\mathrm{OH})_{2}\right](\mathrm{OH})_{3}\right.$ also had peaks at $2 \theta$ values of $13.8^{\circ}, 18.2^{\circ}, 22.5^{\circ}, 27.8^{\circ}, 30.5^{\circ}, 33.6^{\circ}, 35.1^{\circ}, 39.5^{\circ}$, $43.4^{\circ}, 52.4^{\circ}, 58.6^{\circ}[14]$. Since some of the peaks of $\mathrm{Cu}_{2}\left[\left(\mathrm{BO}(\mathrm{OH})_{2}\right](\mathrm{OH})_{3}\right.$ were present in the X-ray diagram it could also be present in the powder.

The peaks related to $\mathrm{Cu}\left(\mathrm{BO}_{2}\right)_{2}$ should have been observed at $2 \theta$ values of $13.9^{\circ}, 16.7^{\circ}, 22.9^{\circ}, 28.7^{\circ}$, $33.8^{\circ}, 35.9^{\circ}, 8.09^{\circ}, 41.7^{\circ}, 46.7^{\circ}$ as reported in JSPDS card number 01-472 for $\mathrm{Cu}\left(\mathrm{BO}_{2}\right)_{2}$. Due to the absence of these peaks, $\mathrm{Cu}\left(\mathrm{BO}_{2}\right)_{2}$ was not present.

$\mathrm{X}$ ray diffraction diagram of the powder obtained at 8.2 without Span 60 is seen in Fig. 4c. It is very similar to the one with Span 60. There are no sharp diffraction peaks. There were broad diffraction peaks being maximum at $2 \theta$ values of $5.0^{\circ}, 9.4^{\circ}, 30.6^{\circ}$ and $37.6^{\circ}$. Due to the nanosize of the particles, even if they were crystalline, their diffraction peaks were broadened and overlapped with each other. Thus it was not possible to say which crystalline phase was present in the powder by examining its X-ray diffraction diagram. 


\subsection{Functional Groups in Precipitates}

Typical FTIR spectra of the powders obtained at $\mathrm{pH}$ 3.7, 10.1 and 8.2 are seen in Fig. 5. FTIR spectrum of the sample produced at $70{ }^{\circ} \mathrm{C}$ without Span 60 for $4 \mathrm{~h}$ at $\mathrm{pH} 3.7$ is the curve 1 in Fig. 5. All other samples prepared at $\mathrm{pH} 3.7$ also exhibit the similar spectra with this sample. The peaks at 3,547 and 3,491 $\mathrm{cm}^{-1}$ belong isolated and hydrogen bonded $\mathrm{OH}$ stretching peaks. The peaks at 1,422 and $1,360 \mathrm{~cm}^{-1}$ are asymmetric and symmetric stretching peaks of $\mathrm{O}-\mathrm{NO}_{2}$ respectively. The peak at at $1,047 \mathrm{~cm}^{-1}$ is attributed to $\mathrm{N}-\mathrm{O}$ stretching vibration of monodendate O-NO groups [9]. The peaks at 869,767 and 669 are due to bending vibrations of $\mathrm{Cu}-\mathrm{OH}$ groups with different hydrogen bonds. The IR spectrum of copper hydroxy nitrate prepared by previous investigators $[8,11]$ is very similar to those of the precipitates obtained by Method 1 .

The infrared spectrum of the powder obtained at $\mathrm{pH}$ 8.2 without Span 60 is shown by the curve 3 in Fig. 5. There is a broad peak at $3,416 \mathrm{~cm}^{-1}$ which represented the vibrations of hydrogen bonded O-H group. Bending vibrations of $\mathrm{H}_{2} \mathrm{O}$ is observed at $1,620 \mathrm{~cm}^{-1}$. Asymmetric and symmetric stretching of the $\mathrm{B}(3)-\mathrm{O}$ group was observed at $1,383 \mathrm{~cm}^{-1}$ and $977 \mathrm{~cm}^{-1}$. At 1230 $\mathrm{cm}^{-1}$ in plane bending of $\mathrm{B}-\mathrm{OH}$ is observed. Out of plane bending of $\mathrm{B}(3)-\mathrm{O}$ gave a small peak at $684 \mathrm{~cm}^{-1}$.

The FTIR spectrum of the product obtained at $\mathrm{pH} 8.2$ is shown by the curve 2 in Fig. 5. The shoulder at 3,543 $\mathrm{cm}^{-1}$ belongs to isolated $\mathrm{OH}$ groups vibrations. The broad peak being maximum at $3,468 \mathrm{~cm}^{-1}$ is due to vibrations of hydrogen bonded $\mathrm{OH}$ groups. The $\mathrm{OH}$ bending vibration is observed at $1,620 \mathrm{~cm}^{-1}$. The peaks observed at 1,417, 1,384 and $1,340 \mathrm{~cm}^{-1}$ are for the asymmetric stretching vibrations of $\mathrm{B}(3)-\mathrm{O}$ group. The peak at $1,230 \mathrm{~cm}^{-1}$ is due to in plane bending of $\mathrm{B}-\mathrm{OH}$ group. The peak at $667 \mathrm{~cm}^{-1}$ or for the out of plane bending vibrations of the $\mathrm{B}(3)-\mathrm{O}[15,16]$.

\subsection{Thermal Characterization of the Precipitates}

TG curve for the sample prepared at $70{ }^{\circ} \mathrm{C}$ with Span 60 and mixed for $2 \mathrm{~h}$ at pH 3.7 is the curve 1 in Fig. 6.

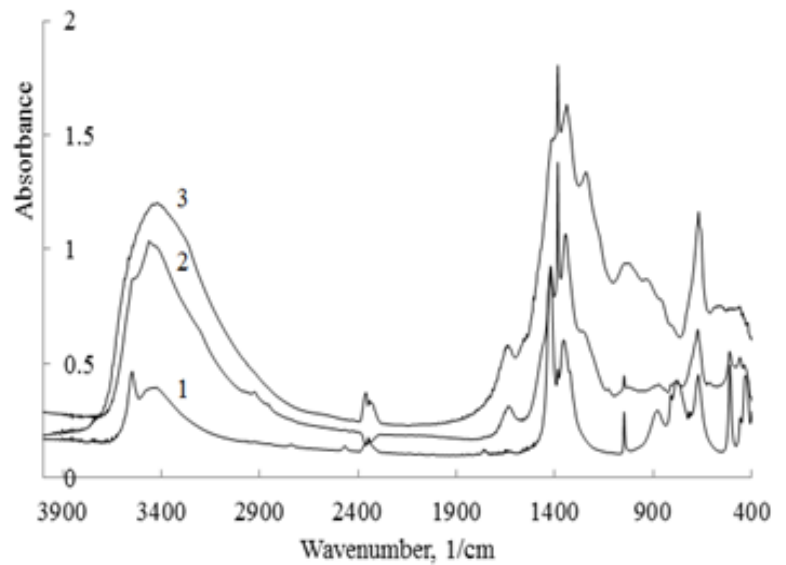

Fig. 5 FTIR spectra of samples prepared without Span 60 (1) at $70{ }^{\circ} \mathrm{C}$ reacted for $2 \mathrm{~h}$ at $\mathrm{pH} 3.7$, (2) at $60{ }^{\circ} \mathrm{C} \mathrm{pH} 10.2$ and (3) at $25^{\circ} \mathrm{C}$ and at $\mathrm{pH} 8.2$.

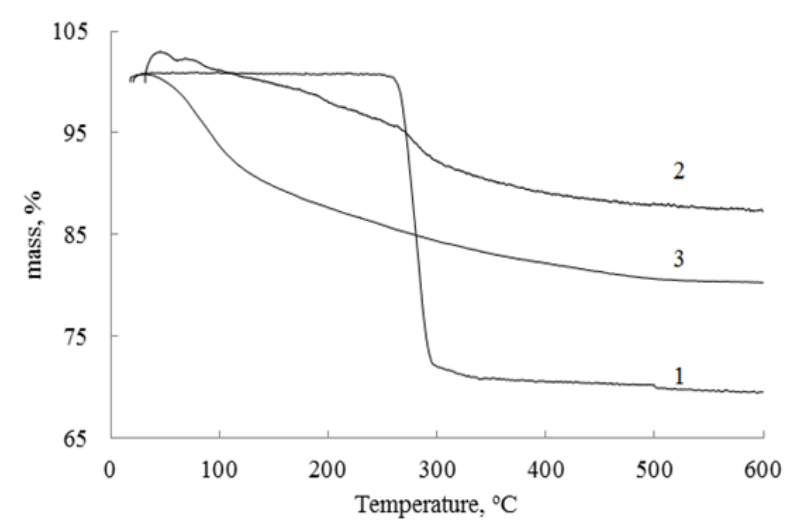

Fig. 6 TG curve of the samples prepared (1) at $70{ }^{\circ} \mathrm{C}$ with Span 60 and reacted for $2 \mathrm{~h}$ at $\mathrm{pH} 3.7$, (2) at $\mathrm{pH} 10.2$ and (3) at $\mathrm{pH} 8.2$ without Span 60.

Other samples prepared at $\mathrm{pH} 3.7$ had TG curves similar to this one. Since the FTIR spectroscopy indicated these powders had the same spectrum with copper hydroxy nitrate, their thermal decomposition behavior should be similar to that of copper hydroxy nitrate. The most commonly accepted mechanism for the thermal decomposition of copper hydroxyl nitrate is described by Eq. (2) [9].

$\mathrm{Cu}_{2}(\mathrm{OH})_{3}(\mathrm{NO})_{3}(\mathrm{~s}) \rightarrow 2 \mathrm{CuO}(\mathrm{s})+\mathrm{HNO}_{3}(\mathrm{~g})+\mathrm{H}_{2} \mathrm{O}(\mathrm{g})(2)$

De-hydroxylation and decomposition of the anion in the interlayer space should take place leading to the destruction of the layered structure during heating. The temperature of the thermal decomposition process of copper hydroxyl nitrate was reported to be $246{ }^{\circ} \mathrm{C}$ [9] which was very close to those of the precipitates obtained in the present study. The mass loss onset 
temperatures of the all samples were between 237.7 and $248.7{ }^{\circ} \mathrm{C}$ as shown in Table S1. The remaining mass after thermal decomposition would be $66 \%$ considering the stoichiometry of the reaction in Eq. 2. The remained mass from the samples at $600{ }^{\circ} \mathrm{C}$ were in the range of $63.4 \%$ and $70.9 \%$ as indicated in Table S1. The higher values of remained mass than $66 \%$ indicated that there were other nonvolatile components such as a borate compound in the precipitates.

TG curves for precipitates prepared at $\mathrm{pH} 10.1$ and 8.2 without Span 60 are shown by the curves 2 and 3 in Fig. 6. Their TG curves do not have a step change like the powders obtained at $\mathrm{pH}$ 3.7. The mass losses for these compounds are due to elimination of free water up to $100{ }^{\circ} \mathrm{C}$ and of bound water as $\mathrm{OH}$ groups above this temperature. There is a smooth mass loss down to $96 \%$ at $258{ }^{\circ} \mathrm{C}$ and it decreases at a faster rate down to $93 \%$ at $295{ }^{\circ} \mathrm{C}$ and the remaining mass at $600{ }^{\circ} \mathrm{C}$ is $87 \%$ for the powder prepared at $\mathrm{pH} 10.1$. It can be concluded the $13 \%$ mass loss was due to elimination of free and bound water from the sample. Since the powder prepared at $\mathrm{pH} 8.2$ was only dried at $25{ }^{\circ} \mathrm{C}$, it had a high value of free water content. As seen in the curve 3 in Fig. 6 there is a smooth mass loss down to $92 \%$ at $100{ }^{\circ} \mathrm{C}$ and the mass loss continues at a slower rate at higher temperatures. The remaining mass is $80 \%$ at $600{ }^{\circ} \mathrm{C}$. In other words there are $8 \%$ free water and $12 \%$ bound water in this sample.

DSC curve of the sample prepared at $70{ }^{\circ} \mathrm{C}$ with Span 60 and mixed for $2 \mathrm{~h}$ at $\mathrm{pH} 3.7$ is given by the curve 1 in Fig. 7. The DSC curves of the other samples prepared at $\mathrm{pH} 3.7$ were also similar to this curve. As reported in Table S1 all the samples decomposed by an endothermic reaction and the heat of decomposition were between 640.2 and $996.8 \mathrm{~J} / \mathrm{g}$ as determined from the area of the peak with $260{ }^{\circ} \mathrm{C}$ maximum. The curve 2 in Fig. 7 is for the sample prepared at $\mathrm{pH}$ 10.1. It does not show any sharp dehydration or decomposition peak. The curve 3 in Fig. 7 is for sample prepared at pH 8.2 and it has an endothermic peak being maximum around $77{ }^{\circ} \mathrm{C}$. This peak corresponds to $8 \%$ mass loss observed in TG curves and it is related to desorption of free water from the sample.

\subsection{The in Situ Drift FTIR Spectroscopy}

The in situ drift FTIR spectroscopy study of the samples give information about the functional groups on the surface of the particles. In Fig. 8a, 8b and 8c in situ drift spectra of the samples during heating them from $25{ }^{\circ} \mathrm{C}$ to $600{ }^{\circ} \mathrm{C}$ at $2{ }^{\circ} \mathrm{C} / \mathrm{min}$ heating rate are exhibited. The spectra taken during heating of the sample prepared at $\mathrm{pH} 3.7$ showed the elimination of $\mathrm{OH}$ groups and $\mathrm{NO}_{3}^{-}$ions by heating (Fig. 8a). The peaks related to $\mathrm{OH}$ groups at $3,520 \mathrm{~cm}^{-1}$ and $3,400 \mathrm{~cm}^{-1}$ and the peaks related to nitrate ions at $1,411 \mathrm{~cm}^{-1}$ and $1,327 \mathrm{~cm}^{-1}$ disappeared after thermal decomposition. A new peak appeared at $1,344 \mathrm{~cm}^{-1}$ at $300{ }^{\circ} \mathrm{C}$ which could be due to stretching vibrations of three coordinate boron, $\mathrm{B}(3)-\mathrm{O}$ groups $[15,16]$. This peak overlapped with the peaks of nitrate groups in unheated samples and it was clearly observed when nitrate groups were eliminated from the sample by heating.

The drift FTIR spectra of the powder prepared at $\mathrm{pH}$ 10.1 are seen in Fig. 8b. There is a broad peak at 3,400 $\mathrm{cm}^{-1}$ which decreases in intensity on heating. This shows hydrogen bonded $\mathrm{OH}$ groups are removed on heating the sample. The broad peak being maximum at $1,357 \mathrm{~cm}^{-1}$ which belong to $\mathrm{B}(3)-\mathrm{O}$ vibrations did not

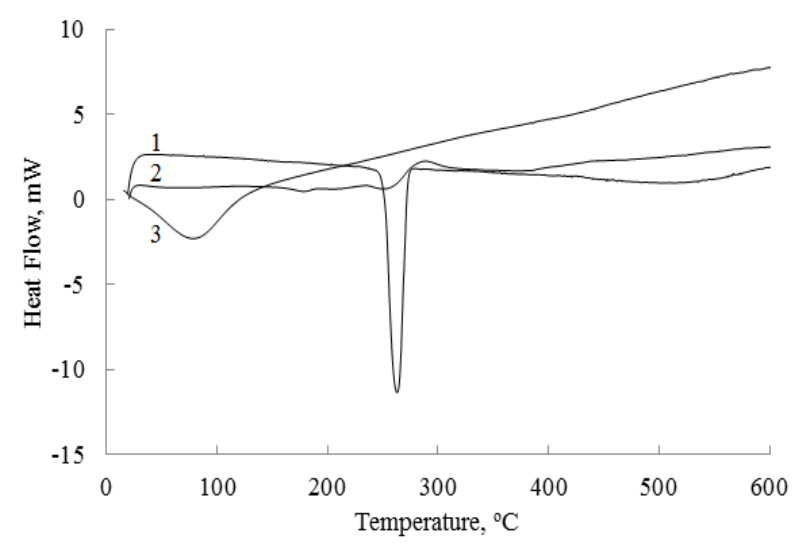

Fig. 7 DSC curve of samples prepared 1. at $70{ }^{\circ} \mathrm{C}$ with Span 60 and reacted for $2 \mathrm{~h}$ at $\mathrm{pH} 3.7,2$. at $\mathrm{pH} 10.2,3$. at $\mathrm{pH}$ 8.2 without Span 60 . 


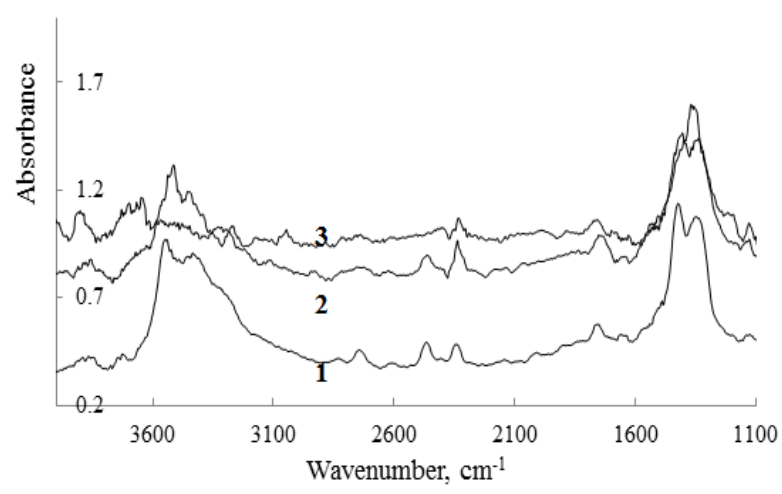

(a)

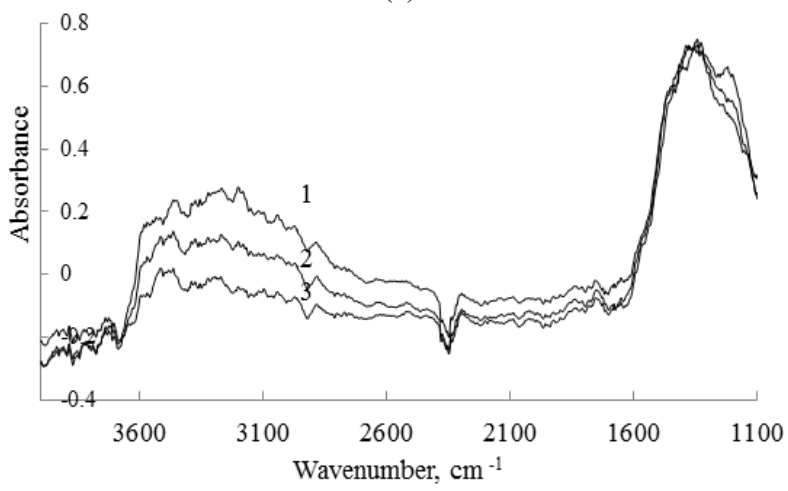

(b)

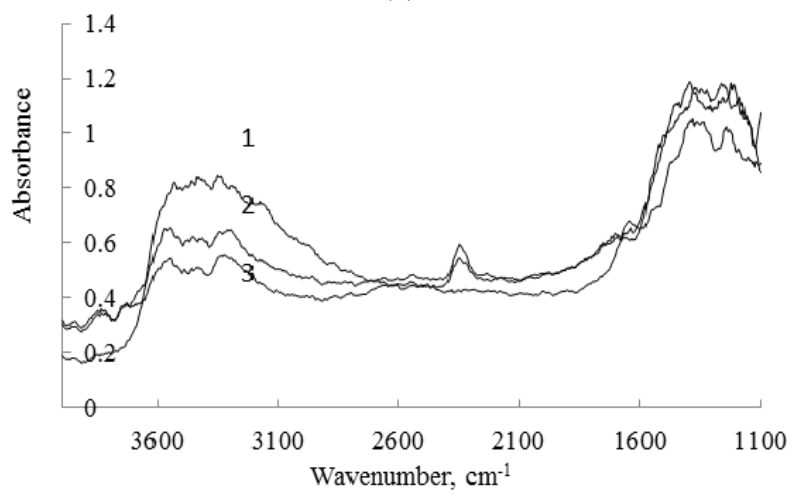

(c)

Fig. 8 Drift FTIR spectra of the samples produced (a) at $70{ }^{\circ} \mathrm{C}$ without Span 60 and reacted for $2 \mathrm{~h}$ at $\mathrm{pH} 3.7$, (b) $\mathrm{pH}$ 10.1 , (c) at $\mathrm{pH} 8.2$ without Span 60; at (1) $25{ }^{\circ} \mathrm{C}$, (2) $200{ }^{\circ} \mathrm{C}$, (3) $300{ }^{\circ} \mathrm{C}$ during dynamic heating experiment.

show any change in intensity on heating. A small shoulder was observed for B-OH stretching vibration at $1,210 \mathrm{~cm}^{-1}$ at $300-500{ }^{\circ} \mathrm{C}$.

The drift FTIR spectra of the powder prepared at $\mathrm{pH}$ 8.2 without Span 60 are seen in Fig. 8c. The hydrogen bonded $\mathrm{OH}$ peak around $3,400 \mathrm{~cm}^{-1}$ decrease in intensity and $\mathrm{B}(3)-\mathrm{O}$ asymmetric vibrations peaks at $1,350 \mathrm{~cm}^{-1}$ and $\mathrm{B}-\mathrm{OH}$ stretching vibration at $1,213 \mathrm{~cm}^{-1}$ increase in intensity on heating.

The dehydration kinetics of the samples prepared at pH 3.7, pH 8.2 and $\mathrm{pH} 10.1$ were examined by in situ FTIR spectroscopy. The change of the ratio of the absorbance of the hydrogen bonded $\mathrm{OH}$ peak at 3,400 $\mathrm{cm}^{-1}$ at any temperature (A) to the absorbance at $25^{\circ} \mathrm{C}$ $\left(A_{o}\right)$ versus temperature of the samples prepared at different $\mathrm{pH}$ values during dynamic heating in DRIFT cell are shown in Fig. 9. As seen in the figure the sample prepared at $\mathrm{pH} 3.7$ dehydrated totally at $300{ }^{\circ} \mathrm{C}$, and the samples prepared at $\mathrm{pH} 8.2$ and at $\mathrm{pH}$ 10.1 continued to dehydration up to $500{ }^{\circ} \mathrm{C}$. Dehydration rates of the sample prepared at $\mathrm{pH} 10.1$ and $\mathrm{pH} 8.2$ were close to each other indicating the stability of the $\mathrm{OH}$ groups in their structure were similar to each other. On the other hand, the sample prepared at $\mathrm{pH} 3.7$ had $\mathrm{OH}$ groups which can be removed at a faster rate.

\subsection{Chemical Composition of the Samples}

The precipitates formed from sodium borate and copper nitrate solutions changed in composition depending on the $\mathrm{pH}$, concentration and temperature of drying. Three main methods were used in the present study. Borax/copper ratio was $0.25,0.87$ and 1 for the methods 1,2 and 3 , respectively. The $\mathrm{pH}$ value of the mother liquors in equilibrium with the precipitates were 3.7, 10.1 and 8.1, respectively. Method 3 was for producing nano particles, thus dilute solutions and low

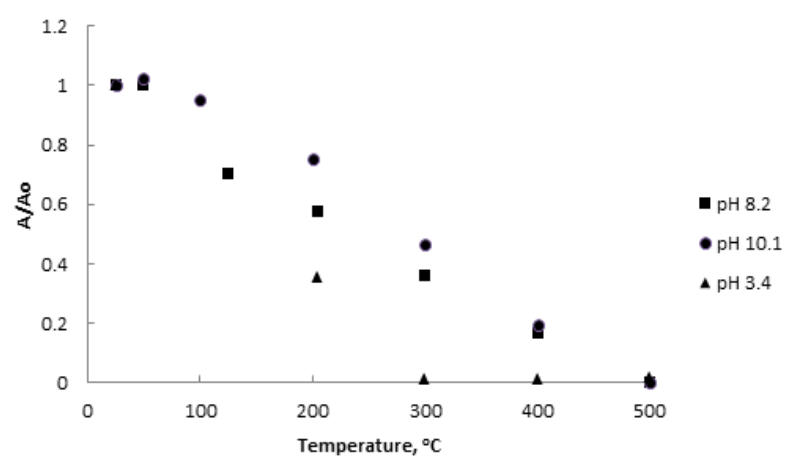

Fig. $9 \mathrm{~A} / \mathbf{A}_{0}$ value at $3,400 \mathrm{~cm}^{-1}$ versus temperature for dynamic heating experiments for samples produced without Span 60 at $70^{\circ} \mathrm{C}$ reacted for $2 \mathrm{~h}$ at $\mathrm{pH} 3.7$, at $\mathrm{pH} 10.1$ and pH 8.2. 
temperature of mixing and drying were used to prevent crystal growth.

The chemical analysis of the samples indicated that they had $\mathrm{Cu}, \mathrm{O}, \mathrm{N}, \mathrm{B}$ and $\mathrm{H}$ elements (Table 5). The reported $\mathrm{Cu}$ and $\mathrm{B}$ content in Table 4 were determined by ICP analysis and analytical titrations respectively. $\mathrm{N}$ and $\mathrm{H}$ content were obtained by CNHS analysis. EDX analysis indicated the presence of $\mathrm{O}$ element. However the reported oxygen content in Table 4 was calculated by mass balance since EDX analysis measured only approximate values for oxygen. The samples prepared under different conditions at $\mathrm{pH} 3.7$ had on the average $47.7 \pm 4.2 \% \mathrm{Cu}, 2.6 \pm 1.2 \% \mathrm{~B}, 5.9 \pm 0.5 \% \mathrm{~N}, 1.2 \pm$ $0.1 \% \mathrm{H}$ and $34.1 \pm 2.6 \% \mathrm{O}$ elements. FTIR spectroscopy demonstrated that nitrogen existed as nitrate ions and $\mathrm{H}$ atoms were present as $\mathrm{OH}$ groups in the products. B element was present in trigonal coordination $\mathrm{B}(3)-\mathrm{O}$ at $300{ }^{\circ} \mathrm{C}$. X-ray diffraction analysis, TG and FTIR spectroscopy indicated the presence of $\mathrm{Cu}_{2}(\mathrm{OH})_{3} \mathrm{NO}_{3}$ in the precipitates. $\mathrm{Cu}_{2}(\mathrm{OH})_{3} \mathrm{NO}_{3}$ were obtained by adding aqueous sodium carbonate [8], aqueous ammonia [9] or solid $\mathrm{Mg}(\mathrm{OH})_{2}$ [8] to aqueous copper nitrate solution. Neither copper carbonate [7] nor copper tetramine nitrate [9] were formed in these reactions. Only the $\mathrm{OH}$ ions introduced by basic solutions were consumed to form $\mathrm{Cu}_{2}(\mathrm{OH})_{3} \mathrm{NO}_{3}$. Similarly the precipitate having mainly the borate ions was not obtained at $\mathrm{pH} 3.7$ in the present study. $\mathrm{OH}$ ions present in borax solution were consumed only and mainly $\mathrm{Cu}_{2}(\mathrm{OH})_{3} \mathrm{NO}_{3}$ was formed. The average chemical analysis indicated that for each mol of $\mathrm{Cu}_{2}(\mathrm{OH})_{3} \mathrm{NO}_{3}$ there were borate ions equivalent to $0.13 \mathrm{~mol}$ of $\mathrm{Cu}\left(\mathrm{BO}_{2}\right)_{2}$ in the samples. However, $\mathrm{Cu}\left(\mathrm{BO}_{2}\right)_{2}$ peaks were not present in the $\mathrm{x}$-ray diffraction diagram. Some of the nitrate ions should have been replaced by the borate ions in infinite network of $\mathrm{Cu}_{2}(\mathrm{OH})_{3} \mathrm{NO}_{3}$ without changing its crystal structure. Since the partial substitution of nitrate ions of $\mathrm{Cu}_{2}(\mathrm{OH})_{3} \mathrm{NO}_{3}$ by benzoate ions [10], perchlorate ions [14] and hydroxydodecyl sulfate ions [9] were reported in previous studies, some of the nitrate ions
Table 4 Average elemental composition of the samples prepared under different conditions, $\mathrm{Cu}$ from ICP and B Mass \% from analytical titrations, $\mathrm{N}$ and $\mathrm{H}$ from HCNS analysis, $O$ from mass balance.

\begin{tabular}{lllllll}
\hline \multirow{2}{*}{ Method } & \multirow{2}{*}{$\mathrm{pH}$} & \multicolumn{5}{c}{ Elemental composition } \\
\cline { 3 - 7 } & & $\mathrm{Cu}(\%)$ & $\mathrm{B}(\%)$ & $\mathrm{N}(\%)$ & $\mathrm{H}(\%)$ & $\mathrm{O}(\%)$ \\
\hline \multirow{2}{*}{1} & \multirow{2}{*}{3.7} & $47.7 \pm$ & $2.6 \pm$ & $5.9 \pm$ & $1.2 \pm$ & $34.1 \pm$ \\
& & 4.2 & 1.2 & 0.5 & 0.1 & 2.6 \\
2 & \multirow{2}{*}{10.1} & $54.8 \pm$ & $11.8 \pm$ & $1.2 \pm$ & $1.5 \pm$ & $30.7 \pm$ \\
& & 0.2 & 0.2 & 0.1 & 0.1 & 1.1 \\
3 & \multirow{3}{*}{8.2} & $25.0 \pm$ & $5.5 \pm$ & $0.25 \pm$ & $2.2 \pm$ & $67.1 \pm$ \\
& & 0.2 & 0.5 & 0.1 & 0.1 & 0.3 \\
\hline
\end{tabular}

Table 5 Copper and borate conversions of the processes and the mother liquor concentrations in equilibrium with the precipitates.

\begin{tabular}{llllll}
\hline \multirow{2}{*}{ Method } & \multicolumn{3}{l}{$\begin{array}{l}\text { Equilibrum } \\
\mathrm{pH}\end{array}$} & \multicolumn{3}{c}{$\begin{array}{c}\text { Mother liquor } \\
\text { concentrations } \\
\left(\mathrm{mol} / \mathrm{dm}^{3}\right)\end{array}$} \\
\cline { 2 - 6 } & & $\mathrm{Cu}$ & \multicolumn{2}{c}{ Borate $\mathrm{Cu}$} & Borate \\
\hline 1 & 3.7 & 32 & 11 & 0.18 & 0.08 \\
2 & 10.2 & 88 & 38 & 0.04 & 0.16 \\
3 & 8.3 & 39 & 26 & 0.03 & 0.04 \\
\hline
\end{tabular}

should have been replaced by the borate ions in infinite network of $\mathrm{Cu}_{2}(\mathrm{OH})_{3} \mathrm{NO}_{3}$ without changing its crystal structure in the present study. Thus the precipitate obtained at $\mathrm{pH} 3.7$ in the present study is called as copper hydroxy nitrate borate.

There are many parallel reactions that could occur when copper nitrate and borax solutions are mixed. Copper hydroxy nitrate is formed according to reaction shown by Eq. (3).

$$
\begin{gathered}
2 \mathrm{Cu}^{2+}(\mathrm{aq})+3 \mathrm{OH}^{-}(\mathrm{aq})+ \\
\mathrm{NO}_{3}{ }^{-}(\mathrm{aq}) \rightarrow \mathrm{Cu}_{2}(\mathrm{OH})_{3} \mathrm{NO}_{3}(\mathrm{~s})
\end{gathered}
$$

The $\mathrm{pH}$ of the reaction medium after addition of copper nitrate solution to borate solution was 3.7 in Method 1. This emphasized that neutralization of $\mathrm{OH}^{-}$ ions and additionally hydrolysis of water were also taken place releasing protons to the medium as shown in Eq. (4).

$$
\mathrm{Cu}^{2+}(\mathrm{aq})+3 \mathrm{H}_{2} \mathrm{O}(\mathrm{l}) \rightarrow \mathrm{Cu}(\mathrm{OH})_{2}(\mathrm{~s})+2 \mathrm{H}_{3} \mathrm{O}^{+}(\mathrm{aq}) \text { (4) }
$$

A solution rich in copper and borate ions having $\mathrm{pH}$ value 3.7 was remained after separation of the precipitate from the system. At this $\mathrm{pH}$ value it is expected that $\mathrm{B}_{4} \mathrm{O}_{7}^{-2}$ ions are transformed to $\mathrm{H}_{3} \mathrm{BO}_{3}$ : 


$$
\begin{gathered}
\mathrm{B}_{4} \mathrm{O}_{7}^{-2}(\mathrm{aq})+2 \mathrm{H}_{3} \mathrm{O}^{+}(\mathrm{aq})+ \\
3 \mathrm{H}_{2} \mathrm{O}(\mathrm{l}) \rightarrow 4 \mathrm{H}_{3} \mathrm{BO}_{3}(\mathrm{aq})
\end{gathered}
$$

Boric acid is a weak acid having $\mathrm{pK}_{\mathrm{a}}$ value of 9.14 for its first ionization reaction shown in Eq. (6):

$$
\mathrm{B}(\mathrm{OH})_{3}+\mathrm{H}_{2} \mathrm{O} \rightarrow \mathrm{BO}(\mathrm{OH})_{2}^{-}+\mathrm{H}_{3} \mathrm{O}^{+}
$$

$\mathrm{BO}(\mathrm{OH})_{2}{ }^{-}$ions could replace the $\mathrm{NO}_{3}{ }^{-}$ions in copper hydroxy nitrate. The drift FTIR study also confirmed the presence of trigonal $\mathrm{B}(3) \mathrm{O}$ groups at $300{ }^{\circ} \mathrm{C}$ in the precipitate. Thus the precipitate was named as copper hydroxy nitrate borate due to its composition. Even if there were unreacted $\mathrm{Cu}^{2+}$ cations and borate anions in the mother liquid in equilibrium with the precipitates, they did not react to form copper borate $\mathrm{xCuO} . \mathrm{yB}_{2} \mathrm{O}_{3} . \mathrm{zH}_{2} \mathrm{O}$ using at $\mathrm{pH} 3.7$ in the present study.

Excess $\mathrm{OH}^{-}$ions added to the solution reacted with copper ions to form $\mathrm{Cu}(\mathrm{OH})_{2}$ as shown in Eq. (7) and made the equilibrium $\mathrm{pH} 10.1$ in Method 2.

$$
\mathrm{Cu}^{2+}(\mathrm{aq})+\mathrm{OH}^{-}(\mathrm{aq}) \rightarrow \mathrm{Cu}(\mathrm{OH})_{2}(\mathrm{~s})
$$

The $\mathrm{OH}^{-}$ions of the $\mathrm{Cu}(\mathrm{OH})_{2}$ formed (Eq.7) should have been replaced by the borate ions present in the reaction medium. From the TG analysis and elemental composition the empirical formula of the powder obtained by this method was found as $\mathrm{Cu}$ $\left(\mathrm{BO}_{2}\right)_{1.5}(\mathrm{OH})_{0.74} \cdot\left(\mathrm{H}_{2} \mathrm{O}\right)_{0.15}$. It also contained $0.11 \mathrm{~mol}$ $\mathrm{NO}_{3}{ }^{-}$ion per mol. A phase isomorphous with $\mathrm{CuBO}_{2}$ was detected in the sample. $\mathrm{Cu}_{2}\left[\mathrm{BO}(\mathrm{OH})_{2}\right](\mathrm{OH})_{3}$ was reported to have infinite chains of $\mathrm{CuO}_{6}$ octahedra bound with each other with $\mathrm{BO}_{3}$ groups [17]. Formation of $\mathrm{BO}(\mathrm{OH})_{2}{ }^{-}$anions in the solution that will substitute $\mathrm{OH}^{-}$ions in $\mathrm{Cu}(\mathrm{OH})_{2}$ was observed [17].

$$
\begin{gathered}
2 \mathrm{Cu}(\mathrm{OH})_{2}+\mathrm{BO}(\mathrm{OH})_{2}{ }^{-} \rightarrow \\
\mathrm{Cu}_{2}\left[\left(\mathrm{BO}(\mathrm{OH})_{2}\right](\mathrm{OH})_{3}+\mathrm{OH}^{-}\right.
\end{gathered}
$$

Formation of $\mathrm{Cu}_{2}\left[\left(\mathrm{BO}(\mathrm{OH})_{2}\right](\mathrm{OH})_{3}\right.$ would be possible according to Eq. (8).

From TG analysis and chemical composition nanoparticles having the empirical formula $\mathrm{Cu}\left(\mathrm{BO}_{2}\right)_{1.5}\left(\mathrm{H}_{2} \mathrm{O}\right)_{6}$ was obtained by mixing of dilute borate and copper solutions at $\mathrm{pH} 8.2$ and drying at room temperature according to method 3. It contained $0.05 \mathrm{~mol} \mathrm{NO}_{3}{ }^{-}$ions per formula weight. A copper borate with oxide formula of $2 \mathrm{CuO} \cdot 3 \mathrm{~B}_{2} \mathrm{O}_{3} \cdot 6 \mathrm{H}_{2} \mathrm{O}$ was reported by Shvartz and Belousova [5] from boric acid, sodium hydroxide and copper sulfate. The oxide formula of the compound with the empirical formula $\mathrm{Cu}\left(\mathrm{BO}_{2}\right)_{1.5}\left(\mathrm{H}_{2} \mathrm{O}\right)_{6}$ is $2 \mathrm{CuO} \cdot 3 \mathrm{~B}_{2} \mathrm{O}_{3} \cdot 6 \mathrm{H}_{2} \mathrm{O}$. Thus it can be concluded that $2 \mathrm{CuO} \cdot 3 \mathrm{~B}_{2} \mathrm{O}_{3} \cdot 6 \mathrm{H}_{2} \mathrm{O}$ was formed under these conditions. However no information about the crystal structure was obtained from the diagram since the peaks were broadened and overlapped due to small size of the crystals.

\subsection{Conversions of Copper and Boron Elements in the} Processes

The percentage of output $\mathrm{Cu}$ in the precipitate to input $\mathrm{Cu}$ is defined as $\mathrm{Cu}$ conversion of the process. On the other hand the $\mathrm{B}$ conversion is defined as the percentage of output $B$ in the precipitate to input $B$ to the system. Table 6 reports the $\mathrm{Cu}$ and $\mathrm{B}$ conversions of the processes with different formulations. The conversions of the process with method 1 at $\mathrm{pH} 3.7$ were in the range of $32 \%$ for $\mathrm{Cu}$ and $11 \%$ for $\mathrm{B}$ elements respectively for different operating conditions. The $\mathrm{Cu}$ conversion was $88 \%$ and $\mathrm{B}$ conversion was $38 \%$ for Method 2 at $\mathrm{pH}$ 10.1. Method 3 at $\mathrm{pH} 8.2$ had $40 \%$ and $28 \% \mathrm{Cu}$ and boron conversions, respectively. The equilibrium concentrations of the solutions are also reported in Table 5. The solution obtained with method 1 at $\mathrm{pH} 3.7$ contained $0.18 \mathrm{~mol} \cdot \mathrm{dm}^{-3} \mathrm{Cu}(\mathrm{II})$ ions and $0.08 \mathrm{~mol} \cdot \mathrm{dm}^{-3}$ borate ions. The equilibrium $\mathrm{Cu}(\mathrm{II})$ and borate concentration of the solution prepared at $\mathrm{pH} 10.2$ with method 2 were $0.04 \mathrm{~mol} \cdot \mathrm{dm}^{-3}$ and $0.16 \mathrm{~mol} \cdot \mathrm{dm}^{-3}$, respectively. On the other hand the solution prepared at $\mathrm{pH} 8.2$ had 0.03 and 0.04 $\mathrm{mol} \cdot \mathrm{dm}^{-3} \mathrm{Cu}(\mathrm{II})$ and borate concentrations, respectively. All the solutions which are in equilibrium with the precipitates contained borate and copper (II) ions. Shvartz and Belousava [4] also reported metal borate mother liquors that can be used in wood or seed preserving applications as byproducts of zinc borate and copper borate formation from borax and metal sulphates [4]. 


\subsection{The Precipitates as Lubricant Additives}

Since a large number of papers have reported the anti-wear and friction reduction abilities of inorganic particles in oil, the lubrication behavior of precipitates was investigated using a four ball tester. The precipitates tested for lubricating additives had different chemical composition, morphology and particle size. The preparation conditions for tested precipitates were reported in materials and methods section. They were differentiated with their preparation $\mathrm{pH}$ since it was the most important variable.

The changes of the friction coefficients with time for different lubricating oils are seen in Fig. 10. The friction coefficients of the oil without any additive and the oil with $1 \%$ Span 60 were reported as 0.99 and 0.066 respectively in a previous study [18]. However, in the present study they were determined as 2.02 and 0.035. Span 60 was the main component of the additives in the lubricating oil that reduce the friction coefficient. The improvement of friction reduction

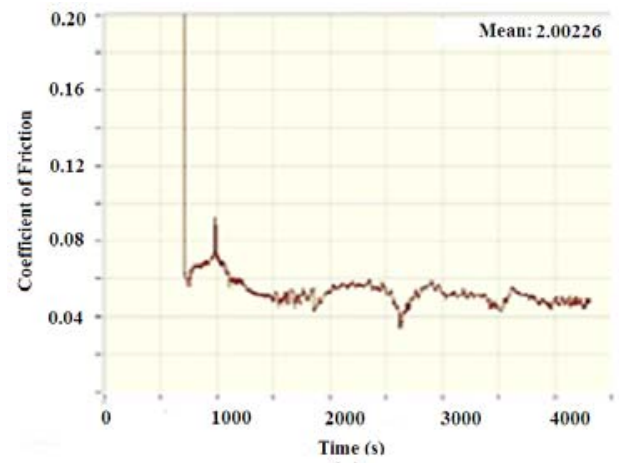

(a)

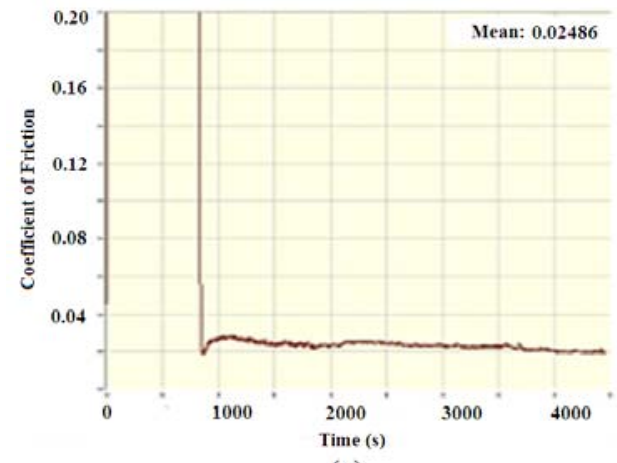

(c) ability of Span 60 can be explained by the formation of a continuous film similar to other surface active agents in concave of rubbing face which can decrease shearing stress [19]. When solid particles were added to mineral oil with Span 60, they will be dispersed homogeneously in lubricating oil since they would be covered with Span 60. The solid particles covered with the surfactant reduce the friction coefficient of the steel surfaces by rolling between them and by filling the imperfections on the surfaces [2]. The change of the friction coefficient depends on the chemical nature, geometry and the size of the solid particles. Submicron sized copper borate particles prepared at $\mathrm{pH} 10.1$ reduced the friction coefficient from 0.035 to 0.025 as seen in Table 6. Nanoparticles prepared at $\mathrm{pH} 8.2$ reduced the friction coefficient to a higher extent, down to 0.012 . Compared to $8 \%$ reduction of friction coefficient by copper nano powders [3], the nano copper borate particles prepared at $\mathrm{pH} 8.2$ in the present study were more efficient with $60 \%$ reduction in friction coefficient. In the literature it was explained

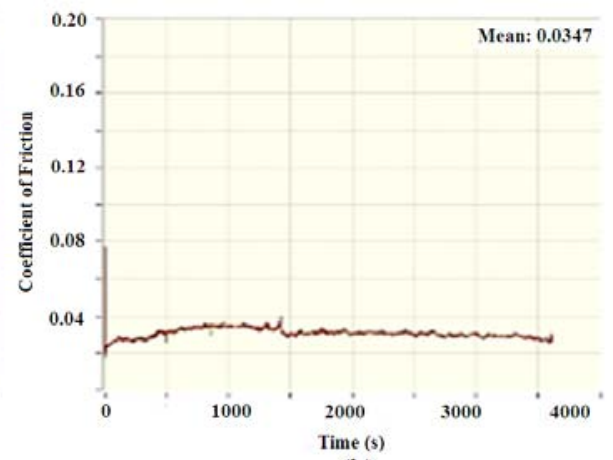

(b)

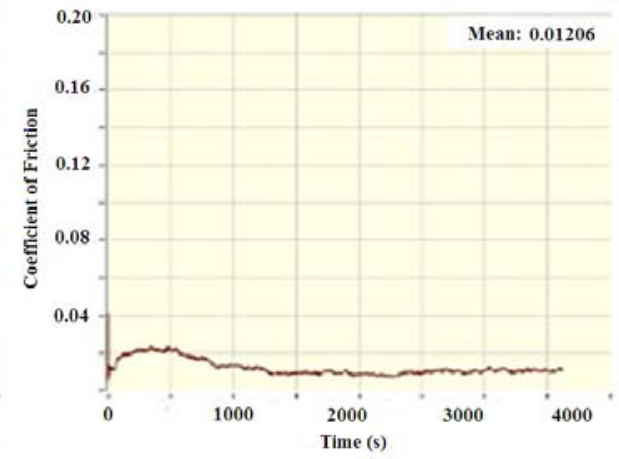

(d)

Fig. 10 Friction coefficient versus time for (a) spindle oil; (b) spindle oil with $1 \%$ Span 60; (c) spindle oil with $1 \%$ Span 60 and $1 \%$ copper borate (pH 10.1) and (d) spind le oil with $1 \%$ Span60 and $1 \%$ copper borate (pH 8.2). 
Table 6 Wear scar diameter and friction coefficient of lubricants.

\begin{tabular}{llll}
\hline Additive & $\begin{array}{l}\text { Average wear scar diameters of } \\
\text { the three fixed balls }(\mu \mathrm{m})\end{array}$ & $\begin{array}{l}\text { Wear scar thickness of the } \\
\text { three fixed balls }(\mu \mathrm{m})\end{array}$ & Friction coefficient \\
\hline None & $806 \pm 14$ & 810 & 2.02 \\
1\% Span 60 & $491 \pm 19$ & 498 & 0.035 \\
1\% Span $60+1 \%$ Copper borate $\mathrm{pH} 10.1$ & $622 \pm 79$ & 640 & 0.025 \\
1\% Span 60+1\% Copper borate $\mathrm{pH} 8.2$ & $532 \pm 19$ & 476 & 0.012 \\
\hline
\end{tabular}

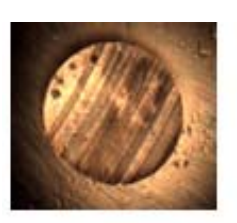

(a)

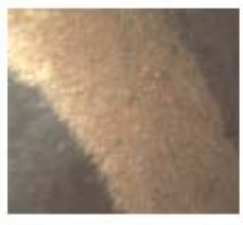

(e)

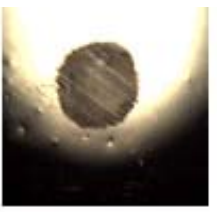

(b)

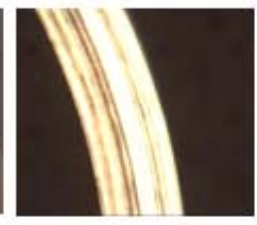

(f)

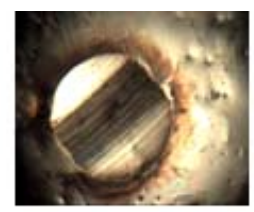

(c)

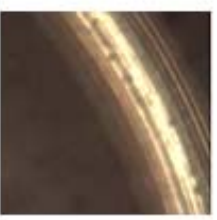

(g)

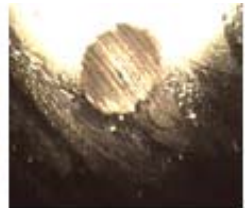

(d)

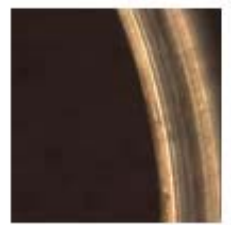

(h)

Fig. 11 Wear scar diameter of fixed and moving balls after testing with lubricating oils. Fixed ball of (a) mineral oil; (b) mineral oil with 1\% Span 60; (c) mineral oil with $1 \%$ Span 60 and $1 \%$ copper borate (pH 10.1) and (d) spindle oil with $1 \%$ Span 60 and $1 \%$ copper borate (pH 8.2), moving ball of (a) mineral oil; (b) mineral oil with 1\% Span 60; (c) mineral oil with $1 \%$ Span 60 and $1 \%$ copper borate (pH 10.1) and (d) mineral oil with $1 \%$ Span60 and $1 \%$ copper borate (pH 8.2).

that the hydrophobic copper borate particles covered with phosphate ester surfactant also had decreased the friction coefficient of lubricating oil more than the unmodified copper borate [2]. In the present study the nonionic surfactant Span 60 was added to make the copper borate particles hydrophobic and a very good result was obtained for the nanoparticles.

The wear scars of representative fixed and moving balls are seen in Fig. 11. The wear scar diameter on fixed ball and the thickness of the ring shaped scar for each oil were very close to each other as seen in Table 6. The wear scar diameter of the fixed ball was $806 \mu \mathrm{m}$ and $494 \mu \mathrm{m}$ for mineral oil and mineral oil with Span 60 as seen in Table 6 . They were reported to be 1,402 $\mu \mathrm{m}, 639 \mu \mathrm{m}$ in a previous study [18]. Both studies indicated the decrease of the wear scar diameter with Span 60 additive. The oil having Span 60 copper borate $\mathrm{pH} 10.1$ had a larger wear scar diameter ( $622 \mu \mathrm{m})$ than that of the oil with only Span $60(494 \mu \mathrm{m})$. On the other hand the wear scar diameter $(532 \mu \mathrm{m})$ of the oil with Span 60 and nano copper borate particles prepared at pH 8.2 were higher than that of the oil with only Span
60. This indicated nano copper borate particles did not reduce the wear scar diameter of lubricating oil with span 60 , but reduced the friction coefficient.

\section{Conclusions}

Particles nanosized only in thickness were obtained as the product of the precipitation process of copper nitrate and sodium borate solutions at $\mathrm{pH} 3.7$ using Method 1 . They were thermally stable up to $237{ }^{\circ} \mathrm{C}$. They contained $\mathrm{Cu}, \mathrm{B}, \mathrm{N}, \mathrm{O}$ and $\mathrm{H}$ elements. The precipitation process operated with low conversions with nearly $35.1 \%-47.9 \%$ for $\mathrm{Cu}$ and $7.0 \%-23.8 \%$ for B elements respectively for a solid precipitate. For each mol of $\mathrm{Cu}_{2}(\mathrm{OH})_{3} \mathrm{NO}_{3}, 0.32$ mols $\mathrm{Cu}\left(\mathrm{BO}_{2}\right)$ appears to be formed. However no crystal peaks related to $\mathrm{Cu}(\mathrm{BO})_{2}$ was observed in the X-ray diagram of the product. Thus it was concluded that the borate ions replaced partially the nitrate ions in $\mathrm{Cu}_{2}(\mathrm{OH})_{3} \mathrm{NO}_{3}$ without changing its crystal structure. Thus the precipitate obtained at $\mathrm{pH} 3.7$ was called as copper hydroxy nitrate borate.

Different products were formed $\mathrm{pH} 10.2$ and 8.2 which can be represented by the empirical formulas $\mathrm{Cu}$ 
$\left(\mathrm{BO}_{2}\right)_{1.5}(\mathrm{OH})_{0.74} \cdot\left(\mathrm{H}_{2} \mathrm{O}\right)_{0.15}$ and $\mathrm{Cu}\left(\mathrm{BO}_{2}\right)_{1.5}\left(\mathrm{H}_{2} \mathrm{O}\right)_{6}$, respectively. Presence of a phase isomorphous with $\mathrm{CuBO}_{2}$ or $\mathrm{Cu}_{2}\left[\left(\mathrm{BO}(\mathrm{OH})_{2}\right](\mathrm{OH})_{3}\right.$ was observed at $\mathrm{pH}$ 10.2. While the The $\mathrm{Cu}$ conversion was $88 \%$ and $40 \%$ and the the $\mathrm{B}$ conversion was $38 \%$ and $28 \%$ for at $\mathrm{pH}$ 10.1 and 8.2, respectively.

For all three methods there were trigonal borate ions in the precipitates as indicated by transmission and drift FTIR spectroscopy. They all had hydrogen bonded $\mathrm{OH}$ groups which were removed by heating them to high temperatures. The products obtained at $\mathrm{pH} 10.1$ and 8.2 also contained water molecules.

The precipitates obtained at $\mathrm{pH} 10.1$ and 8.2 were tested as lubricant additives. When submicron precipitate prepared at $\mathrm{pH} 10.1$ were added to lubricating oil with Span 60, the friction coefficient was reduced $28 \%$. The nanoparticles prepared at $\mathrm{pH}$ 8.2 were more effective in reducing the friction coefficient. They reduced the friction coefficient by $65 \%$. However wear scar diameters were increased compared to addition of only Span 60 .

\section{Acknowledgments}

OPET FUCHS (Izmir Turkey) is acknowledged for four ball tests of the lubricants.

\section{References}

[1] S.Z. Hu, J.X. Dong, G.X. Chen, F. Lou, Preparation of nanometer copper borate with supercritical carbon dioxide drying, Powder Technology 102 (1999) 171.

[2] Y. Zheng, Z. Wang, Y. Tian, Y. Ou, S. Li, D. An, et al., Synthesis and performance of $1 \mathrm{D}$ and 2D Copper borate nano/microstructures with different morphologies, Colloid and Surfaces A: Physicochem. and Eng. Aspects. 349 (2009) 156.

[3] H.L. Yu, Y. Xu, P.J. Shi, B.S. Xu, X.L. Wang, Q. Liu, Tribological properties and lubricating mechanisms of $\mathrm{Cu}$ nanoparticles İn lubricant, Trans. Nonferrous Met. Soc. China 18 (2008) 636.

[4] E.M. Shvartz, R.G. Belousova, Synthesis of Zinc and copper borates in a single technological cycle, Russian Journal of Applied Chemistry 79 (2005) 893.

[5] E.M. Shvartz, R.G. Belousova, Formation of tricuprotetraborate $3 \mathrm{CuO} \cdot 2 \mathrm{~B}_{2} \mathrm{O}_{3} \cdot 6 \mathrm{H}_{2} \mathrm{O}$ in aqueous solutions, Russian Journal of Applied Chemistry 79 (2006) 672.
[6] S.C. Neumair, R. Kaindl, R.D. Hoffmman, H. Huppertz, The New High-Pressure Borate Hydrate $\mathrm{Cu}_{3} \mathrm{~B}_{6} \mathrm{O}_{12} \cdot \mathrm{H}_{2} \mathrm{O}$, Solid State Sciences 14 (2012) 229.

[7] E.J. Bushong, C.H. Yoder, The synthesis and characterization of rouartite, a copper hydroxy nitrate, An Integrated First-Year Laboratory Project Journal of Chemical Education 86 (2009) 80-81.

[8] J.M. Aguirre, A. Gutiérrez, O. Giraldo, Simple route for the synthesis of copper hydroxy salts, J. Braz. Chem. Soc. 22 (2011) 546.

[9] E. Kandare, G. Chigwada, D. Wang, C.A. Wilkie, J.M. Hossenlopp, Nanostructured layered copper hydroxy dodecyl sulfate: A potential fire retardant for poly(vinylester) (PVE) polm, Deg. And Stab. 91 (2006) 1781.

[10] T. Biswick, W. Jones, A. Pacula, E. Serwicka, Synthesis characterization and anion exchange properties of copper, magnesium, zinc and nickel hydroxy nitrates, Journal of Solid State Chemistry 179 (2006) 49.

[11] T. Biswick, W. Jones, A. Pacula, E. Serwicka, R. Cloots, Study of the morphology of copper hydroxynitrate nanoplatelets obtained by controlled double jet precipitation and urea hydrolysis, Journal of Crystal Growth 254 (2003) 176.

[12] S. Park, H.J. Kim, Unidirectionally aligned copper hydroxide crystalline nanorods from two-dimensional copper hydroxide nitrate, J. Am. Chem. Soc. 126 (2004) 14368-14369.

[13] D.C. Pereira, D. Lúcia, A. Faria, V.R.L. Constantino, $\mathrm{Cu}$ (II) hydroxy salts: Characterization of layered compounds by vibrational spectroscopy, J. Braz. Chem. Soc. 17 (2006) 1651.

[14] A.R. Kampf, G. Favreau, Jacquesdietrichite, $\mathrm{Cu}_{2} \mathrm{BO}(\mathrm{OH})_{2}(\mathrm{OH})_{3}$, a new mineral from tachgagalt mine, morocco: Descpription and crystal structure, Europan Journal of Minerology 16 (2004) 361.

[15] L. Zhihong, G. Bo, H. Mancheng, L. Shuni, X. Shuping, FT-IR and Raman spectroscopic analysis of hydrated cesium borates and their saturated aqueous solution, Specrochimica Acta Part A 59 (2003) 2741.

[16] L. Jun, X. Shupping, G. Shiyang, FT-IR and Raman spectroscopic study of hydrated borates, spectrochimica acta part A: Molecular and biomolecular spectroscopy 51 (1995) 519.

[17] H. Behm, C.H. Baerlocher, X-ray Rietveld Structure Determination of Trihydroxo[dihydroxo(oxo)borato] dicopper(II), $\left[\mathrm{Cu}_{2}\left\{\mathrm{BO}(\mathrm{OH})_{2}\right\}(\mathrm{OH})_{3}\right]$, Acta Cryst. C 41 (1985) 5-7.

[18] S.A. Savrik, D. Balkose, S. Ulku, Synthesis of zinc borate by inverse emulsiontechnique for lubrication, J. Therm. Anal. Calorim. 104 (2011) 605-612.

[19] T. Wasilewski, M.W. Sulek, Paraffin oil solutions of the mixture of sorbitan monolaurate-ethoxylated sorbitan monolaurate as lubricants, Wear 261 (2006) 230. 